\title{
Validity and Reliability of the Dollyo Chagi Taekwondo Kick Instrument
}

\author{
Fitra Febrioni Sukma ${ }^{1 *}$ and Anton Komaini ${ }^{2}$ \\ ${ }^{1,2}$ Faculty of Sports Sciences, Universitas Negeri Padang Padang, Indonesia \\ "Corresponding author. Email: fitrafebrionisukma@ gmail.com;
}

\begin{abstract}
Results of research observations So far, the dollyo chagi taekwondo kick instrument available is an instrument for measuring a test of kick ability skills by counting the number of kicks in a certain time interval. When an athlete kicks several times, the athlete may have an injury to the knee and fall, and the results cannot be used accurately so human errors often occur. Based on this, it is important for the trainer to have data on the speed and strength of a Dolly Chagi kick or a circular or rotating taekwondo athlete. The purpose of this study is that researchers want to conduct research in the development of a sensor technology based Dollyo Chagi kick test instrument. The method used in this research is research and development. The sample used was 10 FIK taekwondo athletes, Padang State University, the results of the research "development of the FIK taekwondo kick test instrument Padang FIK Padang State University" were categorized as a dollyo chagi kick test instrument that could measure the speed and strength of each taekwondo kick. This can be seen from the results of research that the instrument of the DIKO Chagi Taekwondo kick test instrument in Padang State University FIK is feasible to be used as the DIKO Chagi kick test instrument in the Padang State University. Thus it can be concluded that the dollyo chagi kick test instrument which is a technology-based athlete of FIK Padang State University, is suitable for use as an instrument or practice of a circular or turning kick test.
\end{abstract}

Keywords: Instrument test, Kick, Dollyo chagi

\section{INTRODUCTION}

Achievement sports are sports activities that are directed and carried out in order to reach the highest peak of achievement. In coaching and implementing performance Sports require support from various scientific disciplines to achieve peak performance. Technology in sports achievement is used by coaches and athletes to support the implementation of the training process so that it is directed and maximized.

One of the martial arts sports that is also quite good development progress is Taekwondo. Taekwondo martial arts originates from Korea. Not only teaches the physical components and tactics, but taekwondo teaches the athlete's discipline and mentality, as well as other psychological aspects. Taekwondo is a martial arts sport that produces beautiful movements. In the taekwondo sport for the (kyorogi) match category the matches are made in three rounds, each round having 2 (two) times and pausing / resting for 1 (one) minute. In this Kyorugi category a taekwondo athlete is required to have a high intensity and explosive power. The basic techniques in taekwondo that must be possessed by an athlete are "1) Horses (soegi / stance), attack techniques (Kyongkyok Kisul), 3) Tackles (Makki): and, 4) Body targets (Keup So) Yoyok (2002 : 9-39).
Each sport has its own characteristics in accordance with the objectives, the tasks of the movement, and the procedure for its implementation in accordance with the rules and competition. Like taekwondo which has various levels of kick technique skills that show the characteristics of unity of function. This means that the kick skills possessed by taekwondo athletes are a combination of a series of movements into one unit. On this basis, coaches in each sport can classify forms of sports skills by determining what criteria are used in classifying these skills

Previous research has developed the Dollyo Chagi Kick Sport Taekwondo Kick Test Instrument. This tool was developed to determine the level of skill and ability of the Dollyo Chagi kick technique in taekwondo athletes. This tool can measure the speed and power of Dollyo Chagi's kick. On this occasion the validity and reliability values of the Dollyo Chagi Kick Test instrument were used. Product validation is an activity process to assess whether the product design, in this case a new work system will be rationally more effective than the old one or not (Sugiyono 2013: 302).

In order for this development research to be valid, the researchers added a questionnaire in which IT (electronics) and test and measurement experts and Tae Kwon Do material experts filled in according to the 
questions provided or in other words using content validity. Because according to Saifudin Azwar (2010: 42) content validity is validity based on expert opinion that the instrument is feasible to be used as a data collection tool. Evidence of content validity (content validity) is obtained by making agreements from experts (expert judgment), namely material experts and IT experts (electronics). So that the product of the research will be validated by experts or experienced experts to assess new products that have been designed, in order to find out the advantages and disadvantages. Sugiyono (2008) explained that to test the validity of construction, opinions from experts (judgment experts) can be used. In this case after the instrument has been constructed about aspects that will be measured on the basis of a particular theory, it is then consulted with experts. To obtain valid data, it is necessary to use high quality instruments and empirical tests, (Komaini, 2018). After the construction test from the expert and based on empirical experience in the field is completed, it is continued with the trial instrument.

\section{METHODS}

The product that has been produced is a tool to measure Dollyo Chagi's kicking skills in Taekwondo sports. Henceforth it is necessary to test the validity and reliability of the tool. The research method used is descriptive method. The study population was 40 FIK UNP Taekwondo athletes. This research was conducted at the Taekwondo Dojo FIK UNP. November-December 2019 research time. The validity of the Dollyo Chagi kicking instrument in Taekwondo sports using expert validation using the Questionnaire questionnaire used in this study was the evaluation questionnaire or response with the form of answers and assessment information, viz. (1) Strongly disagree / very improper, (2) Not suitable / not feasible, (3) Appropriate / feasible, (4) Very suitable / very feasible, then calculated using the calculation results formula presented in the form of a percentage $(\%)$. The reliability test was carried out. This research was conducted two times, with details of the first test and the second test conducted on the same day (test-retest).

\section{RESULT AND DISCUSSION}

A. Result

1. Test Validity

Validity test is a feasibility test of an instrument developed through expert judgment. The experts consisted of two sports evaluation and test measurement experts from the UNP Sport Science Faculty, two taekwondo branch experts from the UNP Faculty of Sports Science, and the Elktronika Media expert from the Faculty of Engineering, Padang State University.
After applying the validity test it can be seen the results of the validity test empirically and the calculation of reliability in the instrument's carrying.

Table 1. Presentation and Feasibility of Experts

\begin{tabular}{|c|c|c|c|}
\hline No & Expert & Percentage & $\begin{array}{l}\text { Level of } \\
\text { eligibility }\end{array}$ \\
\hline 1 & \multirow{2}{*}{$\begin{array}{c}\text { Evaluation } \\
\text { and exercise } \\
\text { measurement } \\
\text { tests }\end{array}$} & $95 \%$ & $\begin{array}{c}\text { Very Good / } \\
\text { Decent }\end{array}$ \\
\hline 2 & & $98 \%$ & $\begin{array}{c}\text { Very Good / } \\
\text { Decent }\end{array}$ \\
\hline 3 & \multirow{2}{*}{ Electronics } & $95 \%$ & $\begin{array}{c}\text { Very Good / } \\
\text { Decent }\end{array}$ \\
\hline 4 & & $90 \%$ & $\begin{array}{c}\text { Very Good / } \\
\text { Decent }\end{array}$ \\
\hline 5 & \multirow{2}{*}{ Taekwondo } & $86 \%$ & $\begin{array}{c}\text { Very Good / } \\
\text { Decent }\end{array}$ \\
\hline 6 & & $86 \%$ & $\begin{array}{c}\text { Very Good / } \\
\text { Decent }\end{array}$ \\
\hline
\end{tabular}

From the results of the validation by the six experts, if it is averaged, a percentage of $91.6 \%$ is obtained and it can be concluded that the results of the development of the Speed and Strength test instrument of Dolly Chagi can be used in measuring the Speed and Strength of Athlete Tae Kwon Do

\section{Reliability Test}

\section{a). Small Scale Reliability Test}

Reliability test conducted This study was conducted as many as two meetings, with details of the first test and the second test conducted on the same day (test-retest). The following are the results of the calculation of the reliability of small and medium scale data, the speed of the Dolly Chagi kick data which is carried out twice a test and the data is calculated of the correlation between the two data.

From the results of the calculation of the kick speed data in a small scale trial, the value of $r=0.98$ can be said to be highly correlated and significant. Furthermore, the reliability calculation of the strength of the Dolly Chagi kick on a small scale is obtained, the value of $r=0.93$ can be said to be highly correlated and significant.

b). Medium Scale Reliability Test

Here are the results of the calculation of the reliability of the middle group data of the speed of the Dollyo Chagi kick data which was carried out twice the test and the data was done to calculate the correlation between the two data from the calculation results obtained $r$ value of 0.82 , it can be said to be highly correlated and significant. Furthermore, the results of the calculation of the reliability of the middle group data for the strength data of the Dollyo Chagi kick performed two tests and from the calculation results obtained the $r$ 
$=0.94$, it can be said to be highly correlated and significant.

Table 2. Category Correlation Coefficients Small-scale reliability kick speed of Dolly Chagi

\begin{tabular}{|c|l|l|c|l|}
\hline No & Scale Trial & variable & $\begin{array}{c}\text { Coofesi } \\
\text { en } \\
\text { correla } \\
\text { tion }\end{array}$ & Realibility \\
\hline 1 & Small & Speed & 0.98 & Very strong \\
\hline 2 & Small & Strength & 0,93 & Very strong \\
\hline 3 & Intermediate & Speed & 0,82 & Very strong \\
\hline 4 & Intermediate & Strength & 0,94 & Very strong \\
\hline
\end{tabular}

\section{CONCLUSION}

The results of the study concluded that the instrument developed as a dollyo chagi kick test instrument for Taekwondo Athletes for the Speed and Strength of taekwondo athletes is said to be reliable and consistent in taking data on the strength and speed of taekwondi athletes at the Faculty of Sport Sciences, Padang State University.

The validity of the instrument is carried out to determine the size that indicates the level of validity of an instrument. validity is a measure that shows the level of validity or validity of an instrument (Arikunto, 2006). A valid or valid instrument has high validity, on the contrary a less valid instrument means it has low validity. Content validity is the degree to which a test measures the intended scope of content. The validity of items starts with the question of whether the test items represent the desired size of the scope of content, the validity of sampling starts at how well the test represents the entire scope of the overall content, (Hamid, 2011)

Reliability shows the extent to which the results of tests and measurements carried out can be recognized and trusted. Measurement test results conducted with the same object / subject display consistent and relatively similar results (Matondang, 2009). Maryunis (2007) explains reliability is a data collection tool that is determined by a coefficient called a reliability coefficient. Reliability shows consistency regardless of the test. As stated by Hamid (2011) that reliabilias is the level at which a test consistently measures whatever the test measures. Reliability is expressed by numbers, usually as a coefficient, high coefficient shows high reliability. Whereas Arikunto (2006) argues that reliability refers to an understanding that an instrument can be trusted enough to be used as a data collection tool because the instrument is already good.

\section{REFERENCES}

[1] Suryadi, V. Yoyok. 2002. Takwondo Poomse Taeguk. Jakarta: PT Gramedia Pustaka Utama.

[2] Sugiyono, 2014. Metode penelitian kuantitatif kualitatif dan R\&D. Bandung: alfabeta.

[3] Komaini, Anton, dkk. 2018. Development Of Static Flexibility Instrument Based On Sensor Technology. Jurnal Sosioteknologi ITB Bandung Vol 17 No 3.

[4] Azwar, Saifuddin. 2000. Reliabilitas dan Validitas. Yogyakarta: Pustaka Pelajar

[5] Matondag, Zulkifli. 2009. Validitas Dan Reliabilitas Suatu Instrumen Penelitian. Jurnal Tabularasa Pps Unimed Vol.6 No.1

[6] Maryunis, Aleks. 2007. Konsep Dasar Penerapan Statistika dan Teori Probabilitas. Padang: FMIPA UNP.

[7] Arikunto, Suharsimi. 2006. Prosedur Penelitian Suatu Pendekatan Praktik. Jakarta: Rineka Cipta

[8] Sugiyono, 2008. Metode Penelitian Pendidikan Pendekatan Kuantitatif, kualitatif, dan R\&D. Bandung: Alfabeta.

[9] Darmadi, Hamid. 2011. Metode Penelitian Pendidikan. Bandung: Alfabeta.

[10] Ahmad dkk. 2019, Pengaruh Latihan Naik Turun Tangga Terhadap Kemampuan Tendangan Dwi Chagi Atlet Tae Kwon Do, Jurnal Mensana volume 4,nomor 1, ISSN 2527-6451(print), ISSN 2622 0295

[11] Atmaja, A. 2015. Pengembangan Model Tes kecepatan Tendangan Ap HurigiPada Atlet Kyorugi Taekwondo. Yogyakarta : Universitas NegeriYogyakarta 